\title{
EDITORIAL
}

\section{OCULAR MALFORMATIONS AND THE FRUITS OF DEVELOPMENTAL GENETICS}

The accurate organisation of the developing cells and organs of an embryo within the three dimensions of space and one of time is a mystifying and fascinating process. The instructions for such a construct, together with the templates for the building blocks, must all be inherited and 'written' within the embryo's genome. Not unexpectedly, the genes concerned with such complicated instructions can occasionally be faulty and lead to disease. Recent advances in molecular biology have to some extent demystified this process and some of the genes responsible for these instructions have been identified. A detailed review of the rapid advances in the molecular biology of one such developmental ocular entity, Norrie's disease, appears in this issue.'

Advances in developmental biology owe much to the fruit fly (Drosophila melanogaster) and its experimenters, and the details and accompanying terminology of the science can no longer be ignored by the ophthalmologist. In 1984, two teams independently described a DNA sequence common to the genes of Drosophila that were responsible for 'homeotic' mutations (mutations leading to transformations of one body-part into another). ${ }^{2,3}$ The DNA sequence shared by these homeotic genes became known as the 'homeobox' which codes for a 'homeodomain' of 61 amino acids. Interestingly, the homeobox is highly conserved throughout the animal kingdom. ${ }^{4}$ In man and other mammals such genes, known as $H O X$ genes, are arranged in four clusters on separate chromosomes and are expressed in a region-specific fashion along the axis of the embryo, colinear with their arrangement on the genome. The homeodomain peptide binds the DNA of other genes, regulating their transcription and thus orchestrating cell differentiation.

Like the homeobox genes, 'paired box' or PAX genes are also members of a family of developmental control genes which encode transcription factors. Their shared nucleotide motif or 'paired box' consists of 384 nucleotides encoding 128 amino acids, so named following its identification in the paired gene $(p s d)$ of Drosophila. ${ }^{5}$ To date, nine PAX genes have been identified in man and mouse. The primary expression of the Pax genes in the mouse is in the embryo, including the developing central nervous system, ${ }^{6}$ Pax6 being strongly expressed in the developing eye. ${ }^{7}$ Mutations in human PAX6 have been shown to cause aniridia, ${ }^{8}$ which is analogous to the 'small eye' mouse (Sey) due to a mutation of mouse Pax6. A child with Peter's anomaly shown to be deleted for one copy of $P A X 6^{9}$ suggests that this gene may be responsible for a range of anterior segment abnormalities. PAX3 mutations have been identified in patients with 'Waardenburg syndrome', 10,11 a dominantly inherited trait involving deafness and pigmentation abnormalities including heterochromia iridis.

As well as $H O X$ and $P A X$ genes it appears that genes encoding growth factors, retinoic acid receptors and other DNA binding proteins also play a major role in mammalian eye development. ${ }^{7}$ As Black and Redmond ${ }^{1}$ discuss in this issue, part of the Norrie's disease protein shows homology to certain growth factors, although the way in which such proteins interact remains to be elucidated.

The list of ophthalmic disorders awaiting the assignment of causative developmental gene defects must include ocular coloboma, familial cataract, microphthalmia and other anterior segment dysgenesis syndromes. Although primary 'cure' of these conditions may not be possible, the elucidation of the genetic and pathogenetic mechanisms that underlie them might allow a more rational approach to therapy, as well as a more logical classification and a better understanding of their aetiology.

\section{A. R. Webster and A. T. Moore}

\section{References}

1. Black G, Redmond RM. 'The molecular biology of Norrie's disease. Eye 1994;8:491-6.

2. McGinnis W, Levene M, Hafen E, Kuroiwa A, Gehring WJ. A conserved DNA sequence found in homeotic genes of the Drosophila Antennapedia and bithorax complexes. Nature 1984;308:428-33.

3. Scott MP, Weiner AJ. Structural relationships among genes that control development: sequence homology between the Antennapedia, Ultrabithorax, and fushi tarazu loci of Drosophila. Proc Natl Acad Sci USA 1984;81:4115-9.

4. Keynon C. If birds can fly, why can't we? Homeotic genes and evolution. Cell 1994;78:175-80.

5. Frigerio G, Burri M, Bopp D, Baumgartner S, Noll M. Structure of the segmentation gene Paired and the Drosophila PRD gene set as part of a gene network. Cell 1986;47:735-46.

6. Chalepakis G, Stoykova A, Wijnholds J, Tremblay P, Gruss P. Pax: gene regulators in the developing nervous system. J Neurobiol 1993;24:1367-84.

7. Matsuo T. The genes involved in the morphogenesis of the eye. Jpn J Ophthalmol 1993;37:215-51.

8. Ton CCT, Hirvonen H, Miwa H, Weil MM, Monaghan P, Jordan T, van Heyningen V, Hastie ND, et al. Positional cloning and characterization of a paired box and homeobox containing gene from the aniridia region. Cell 1991;67:1059-74.

9. Hanson IM, Fletcher JM, Jordan T, Brown A, Taylor D, Adams RJ, Punnett HH, van Heyningen V. Mutations at the PAX6 locus are found in heterogenous anterior segment malformations including Peter's anomaly. Nature Genet 1994;6:168-73.

10. Tassabehji M, Read AP, Newton VE, Harris R, Balling R, Gruss P, Strachan T. Waardenburg's syndrome patients have mutations in the human homologue of the Pax3 paired box gene. Nature 1992;355:635-6.

11. Baldwin CT, Hoth CF, Amos JA, da-Silva EO, Milunsky A. An exonic mutation in the.HuP2 paired domain gene causes Waardenburg's syndrome. Nature 1992;355:637-8. 